\title{
Penyelesaian Sengketa Kontrak Kerja Konstruksi Melalui Ajudikasi Dan Perbandingan Dengan Arbitrase
}

\author{
I Made Wisnu Suyoga ${ }^{1}$ Yohanes Usfunan² \\ 1Program Studi Magister (S2) Kenotariatan Fakultas Hukum Universitas Udayana, E-mail: \\ wisnu.suyoga@yahoo.com \\ ${ }^{2}$ Fakultas Hukum Universitas Udayana, E-mail: yohanes_usfunan@unud.ac.id
}

\begin{tabular}{l}
\hline Info Artikel \\
\hline Masuk : 4 Februari 2020 \\
Diterima : 9 Juli 2020 \\
Terbit :31 Juli 2020 \\
Keywords : \\
Disputes; Contracts ; \\
Construction; Adjudication; \\
Arbitration. \\
\\
Kata kunci: \\
Sengketa; Kontrak; Sengketa; \\
Ajudikasi; Arbitrase. \\
Corresponding Author: \\
wisnu.suyoga@yahoo.com \\
DOI : \\
10.24843/AC.2020.v05.i02.p03
\end{tabular}

\begin{abstract}
The purpose of this study is to analyze the construction dispute resolution in Indonesia; and comparison of construction work contract dispute resolution through adjudication and arbitration. This type of research is a normative legal research with a statute approach, concept approach and comparative approach. The analysis of legal material in this study was done descriptively, interpretatively, evaluatively and argumentatively. The results of the research show that the settlement of construction disputes in Indonesia is regulated in Article 88 of Law Number 2 of 2017 concerning Construction Services including: Mediation, Conciliation and Arbitration. The comparison of construction work contract dispute resolution through adjudication and arbitration states that adjudication is an arbitration mechanism that is simplified and then adjusted in such a way as to meet the needs of fair dispute resolution.
\end{abstract}

\section{Abstrak}

Tujuan study ini untuk menganalisis penyelesaian sengketa konstruksi di Indonesia; dan perbandingan penyelesaian sengketa kontrak kerja konstruksi melalui ajudikasi dan arbitrase. Jenis penelitian yang digunakan merupakan penelitian hukum normatif dengan pendekatan perundang-undangan, pendekatan konsep dan pendekatan perbandingan. Analisis bahan hukum dalam penelitian ini dilakukan secara deskriptif, interpretatif, evaluatif dan argumentatif analisis. Hasil study menunjukkan penyelesaian sengketa konstruksi di Indonesia diatur dalam Pasal 88 Undang-Undang Nomor 2 Tahun 2017 tentang Jasa Konstruksi meliputi: Mediasi, Konsiliasi dan Arbitrase. Perbandingan antara adjudikasi dan arbitrase dalam fungsinya sebagai penyelesaian sengketa kontrak kerja konstruksi dapat dideskripsikan secara sederhana, bahwa adjudikasi merupakan mekanisme penyelesaian sengketa yang memiliki kemiripan dalam hal karakteristik dengan arbitrase. Namun mekanisme adjudikasi justru bersifat lebih sederhana dibandingkan dengan arbitrase. 


\section{Pendahuluan}

Hukum positif di Indonesia belum memberikan peluang bagi terwujudnya kesetaraan dan keadilan serta perlindungan jaminan pembayaran bagi penyedia jasa konstruksi. Adanya mekanisme penyelesaian sengketa konstruksi melalui ajudikasi yang akan dibentuk oleh asosiasi bidang konstruksi pekerjaan proyek tetap berjalan tanpa hambatan dan berdampak baik bagi pembangunan nasional dan kesejahteraan rakyat. Karena pada UU Nomor 2 Tahun 2017 tentang Jasa Konstruksi dalam Pasal 88 tidak mengatur penyelesaian sengketa melalui mekanisme ajudikasi. Maksud study ini adalah untuk memberikan kontribusi terhadap dunia konstruksi di mana sejauh ini sengketa hanya diselesaikan dengan cara mediasi, konsiliasi dan arbitrase saja.

Bisnis bidang konstruksi memiliki kedudukan penting pada pengembangan keuangan Indonesia. Informasi dari Badan Pusat Statistik (BPS), peran bisnis bidang konstruksi sebesar Rp 330,8 trilyun (10,24\%) terhadap Pendapatan Domestik Bruto (PDB) Nasional Tahun 2018. Hal ini menempatkan sektor konstruksi pada urutan ke-4 dari 17 sektor utama. Peran tadi berkembang terus setiap tahunnya bersama laju perkembangan average 7,5 persen setiap tahunnya. ${ }^{1}$

Bisnis bidang konstruksi tidak hanya berkontribusi pada perkembangan ekonomi saja, tapi berkontribusi pula pada pertumbuhan dan perkembangan. Industri-industri jasa serta barang yang dibutuhkan pada pelaksanaan bisnis konstruksi. Bisnis bidang konstruksi tergolong di antara bisnis yang sangat mendukung perkembangan keuangan Indonesia. Peran bisnis bidang konstruksi penyedia kowongan kerja yang dapat membawa penurunan tingkat tuna karya ataupun menaikkan besarnya penghasilan serta pemakaian publik yang selanjutnya menjadi kontribusi positif kepada pembangunan. Agar bisnis bidang konstruksi berkontribusi terhadap "nilai tambah pembangunan" cara atau manajemennya wajib dikelola dengan efisien, efektif dan profesional dalam segala dimensi pada "proyek-proyek" konstruksi.

Menurut Suntana S. Djatnika, "Pelaksanaan pekerjaan jasa konstruksi untuk melakukan pembangunan infrastruktur dilakukan berdasarkan kontrak kerja konstruksi antara pengguna jasa konstruksi dan pelaksana jasa konstruksi. Kontrak kerja konstruksi sama dengan prinsip kontrak secara umum baik itu terkait dengan syarat sahnya kontrak/perjanjian atau prinsip mengikatnya suatu kontrak/perjanjian bagi para pihak". ${ }^{2}$ Pasal 1 angka8 Undang-Undang Nomor 2 Tahun 2017 tentang Jasa Konstruksi (selanjutnya disebut UU Jasa Konstruksi) mengatur bahwa kontrak kerja konstruksi adalah keseluruhan dokumen kontrak yang mengatur hubungan hukum antara Pengguna Jasa dan Penyedia Jasa dalam penyelenggaraan Jasa Konstruksi.

Mengacu ketentuan Pasal 1 angka8 jo Pasal 47 UU Jasa Konstruksi dapat dikatakan pekerjaan jasa konstruksi merupakan suatu hubungan hukum yang dituangkan dalam bentuk kontrak dengan memiliki syarat-syarat yang telah ditetapkan oleh undangundang. Dengan demikian perjanjian jasa konstruksi yang disusun atas dasar UU yang diakui yang meliputi "Kitab Undang-Undang Hukum Perdata (selanjutnya disebut KUHPerdata)" (Pasal 1320 KUHPerdata mengenai persyaratan keabsahan perjanjian ataupun UU Jasa Konstruksi dapat berlaku sebagai UU untuk pihak-pihak yang bersepakat pada perjanjian (Pasal 1338 KUHPerdata mengenai daya mengikat suatu kontrak).

\footnotetext{
${ }^{1}$ Badan Pusat Statistik. (2018). Survey Perubahan Konstruksi Tahun 2018. Jakarta, hal. 17.

2 Suntana S. Djatnika. (2017). "Persengketaan Dalam Perjanjian Konstruksi". Jurnal Indonesia Arbitration Quarterly Newsletter, Vol.9, No.2,hal.8.
} 
Perjanjian jasa konstruksi adalah perhubungan hukum perdata di antara users dengan kontraktor, perhubungan hukum tadi umumnya mengikuti Pasal 1313 KUHPerdata mengenai ikatan perjanjian, Pasal 1320 KUHPerdata mengenai persyaratan keabsahan perjanjian serta Pasal 1338 KUHPerdata mengenai keberlakuan perjanjian sebagai UU untuk pihak-pihak yang terlibat, sedang pada khususnya syarat perjanjian diatur pada Pasal 47 UUJasaKonstruksi. Dengan demikian para pihak dalam perjanjian bisnis konstruksi wajib patuh pada perjanjian yang sudah dibuat yang berlaku sebagai UU bagi pihak-pihak yang terlibat.

Tony Mc Adams menyatakan bahwa "Penyelesaian sengketa konstruksi dimana sengketa konstruksi termasuk sengketa bisnis, lebih diupayakan menggunakan jalur non-liligasi. Hal ini disebabkan, karena kalangan bisnis menilai bahwa penyelesaian sengketa melalui litigasi atau pengadilan berjalan dijalur yang lambat dan memakan biaya yang tidak sedikit. Kalangan pebisnis Amerika menuduh bahwa hancurnya perekonomian nasional diakibatkan oleh mahalnya biaya peradilan". ${ }^{3}$ Selain itu bisnis jasa konstruksi merupakan suatu kontrak bisnis, sehingga timbul kekhawatiran apabila penyelesaian sengketa melalui proses litigasi akan menyebabkan beberapa kesepakatan yang tertuang dalam kontrak konstruksi yang seharusnya menjadi rahasia antar pihak akan diketahui umum. Dengan demikian, Alternatif Penyelesaian Sengketa (APS) merupakan suatu hal yang paling efektif dan efisien dalam menyelesaikan sengketa atau konflik kepentingan dan pemenuhan kebutuhan. ${ }^{4}$

Menurut Erman Rajagukguk, bahwa masyarakat khususnya kaum bisnis termasuk bisnis jasa konstruksi lebih menyukai penyelesaian sengketa di luar pengadilan disebabkan tiga alasan, yaitu Pertama, penyelesaian sengketa di pengadilan adalah terbuka, kaum bisnis lebih menyukai sengketa mereka diselesaikan tertutup, tanpa diketahui oleh publik. Kedua, sebagian masyarakat, khususnya orang bisnis menganggap hakim tidak selalu ahli dalam permasalahan sengketa yang timbul. Ketiga, penyelesaian sengketa di Pengadilan akan mencari pihak mana yang salah dan yang benar, sedangkan putusan penyelesaian sengketa di luar pengadilan akan dicapai melalui kompromi. ${ }^{5}$

Penyelesaian sengketa dengan ajudikasi tidak lazim dilakukan di negara dengan sistem Eropa Kontinental Law, termasuk Indonesia. Penyelesaian sengketa konstruksi melalui ajudikasi telah diperkenalkan di Inggris pada tahun 1998 berdasarkan UU Inggris. Tujuan ajudikasi ini adalah untuk mempersiapkan bagi salah satu pihak yyang membuat perjanjian konstruksi untuk dapat memanggil (menunjuk) seorang ajudikator. Seorang ajudikator akan membuat sebuah keputusan yang mengikat tidak lebih dari 28 hari, dan Pengadilan harus siap untuk melaksanakan putusan itu (enforce).

Selain di Inggris, Negara lain yang juga telah menetapkan prosedur ajudikasi serupa adalah Selandia Baru, Australia dan Singapura. Sementara Malaysia merupakan negara terakhir yang menetapkankan prosedur ajudikasi. Undang-Undang Pembayaran Industri Konstruksi dan Ajudikasi tahun 2012 telah mendapat persetujuan dari Kerajaan Malaysia pada tanggal 18 Juni 2012. Prosedur yang berlaku

3 Tony Mc Adams. (2002). Law Bussiness Society. Boston: Irwin, hal.195.

4 Rachmadi Usman. (2013). Pilihan Penyelesaian Sengketa di Luar Pengadilan. Bandung: PT Citra Aditya Bakti, hal. 41.

${ }^{5}$ Eman Rajagukguk. (2001). Arbitrase dalam Putusan Pengadilan. Jakarta: Chandra Pratama, hal. 30. 
adalah untuk kontrak konstruksi, dan penunjukkan ajudikator oleh Kuala Lumpur Regional Centre for Arbitration (KLRCA). Ajudikator memiliki waktu 45 hari kerja setelah terbitnya jawaban (balasan) atas klaim, kemudian setelah itu ajudikator dapat mengeluarkan (membuat) sebuah putusan tertulis.

Undang-Undang Malaysia Tahun 2012 tersebut mensyaratkan para pihak awalnya untuk mengikuti mekanisme pembayaran yang telah diatur pada kontrak konstruksi mereka. Apabila satu pihak tetap belum dibayar, maka kemudian prosedur pra ajudikasi dapat dipergunakan. Ini mensyaratkan sebuah klaim pembayaran yang berdasarkan "klaim belum dibayar" pada kontrak konstruksi. Pihak termohon kemudian dapat mengakui klaim itu atau mempersengketakannya baik secara keseluruhan atau sebagiannya saja dalam jangka waktu 10 hari sejak klaim itu muncul. Sebuah sengketa yang telah secara jelas terjadi sejak adanya klaim dapat dirujuk ke ajudikasi. Penelitian ini bermaksud menganalisis penyelesaian sengketa kontrak kerja konstruksi melalui ajudikasi dan perbandingan dengan arbitrase.

Berdasarkan latar belakang yang telah diuraikan, menarik untuk dikaji terkait penyelesaian sengketa konstruksi di Indonesia dan perbandingan penyelesaian sengketa konstruksi di Indonesia dan perbandingan penyelesaian sengketa kontrak kerja konstruksi melalui ajudikasi dan arbitrase.

\section{Metodologi Penelitian}

Riset ini menggunakan jenis penelitian yuridis normatif. Menurut I Made Pasek Diantha, "penelitian hukum normatif berfungsi untuk memberi argumentasi yuridis ketika terjadi kekosongan, kekaburan dan konflik norma. Lebih jauh ini berarti penelitian hukum normatif berperan untuk mempertahankan aspek kritis dari keilmuan hukumnya sebagai ilmu normatif". ${ }^{6}$ Approach yang dipakai meliputi statue approach, conceptual approach serta comparative approach. Sumber bahan hukum yang diperlukan meliputi bahan hukum primer, bahan hukum sekunder dan bahan hukum tertier. Metode untuk pengumpulan bahan hukum yang digunakan adalah metode studi kepustakaan. Dokumen atau bahan hukum yang terkumpul diolah dan dikelompokkan berdasarkan "nama pengarang/penulis, judul buku, halaman dan mengutip hal-hal yang dianggap penting agar bisa menjawab permasalahan dalam penelitian ini". 7 Pada penelitian hukum normatif yang dianalisis bukanlah data, melainkan melalui bahan hukum seperti tersebut di atas. Analisis bahan hukum yang berhasil dikumpulkan dalam penelitian ini akan dilakukan secara normatif. Pendekatan yuridis normatif dilakukan dengan cara menelaah dan menginterpretasikan hal-hal yang bersifat teoritis yang menyangkut asas, konsepsi, doktrin dan norma hukum.

\section{Hasil dan Pembahasan}

\subsection{Penyelesaian Sengketa Konstruksi di Indonesia}

Penyelesaian sengketa konstruksi selama ini banyak dilakukan lewat jalan peradilan dengan hakim yang bukan ahli konstruksi dan oleh karenanya putusannya dirasa

\footnotetext{
${ }^{6}$ I Made Pasek Diantha. (2017). Metodologi Penelitian Hukum Normatif dalam Justifikasi Teori Hukum. Jakarta: Prenada Media Group, hal.12.

7 Soerjono Soekanto dan Sri Mahmudji. (2013). Penelitian Hukum Normatif, Suatu Tinjauan Singkat. Jakarta: Raja Grafindo Persada, hal. 13.
} 
tidak adil untuk pihak-pihak yang berselisih. Sebagai contoh, permasalahan hukum/perselisihan dalam pelaksanaan proyek konstruksi di Departemen PUPR yang lewat jalur pengadilan, tidak tertangani dengan optimal dikarenakan penetapan keputusan yang lama dan tidak adanya pemaksaan dari pengadilan kepada pihak yang kalah/bersalah untuk segera memenuhi kewajiban dan konsekuensi yang ditetapkan. Lain dari itu, mekanisme peradilan yang memakan waktu serta berlarutlarut, dinilai tidak mendukung pertumbuhan bidang konstruksi. Oleh karena itu, proses penyelesaian sengketa konstruksi dilakukan di luar pengadilan melalui konsiliasi, mediasi, dan arbitrase.

Pasal 88 UU Jasa Konstruksi mengatur:

"Penyelesaian sengketa yang timbul dari Kontrak Kerja Konstruksi diselesaikan melalui musyawarah untuk mufakat. Dalam hal para pihak yang bersengketa tidak menemukan kesepakatan, maka penyelesaian sengketa ditempuh melalui tahapan upaya penyelesaian sengketa yang tercantum dalam Kontrak Kerja Konstruksi atau dalam hal tidak tercantum dalam Kontrak Kerja Konstruksi, para pihak bersengketa membuat suatu persetujuan tertulis mengenai tata acara penyelesaian sengketa yang akan dipilih".

Langkah-langkah penyelesaian perselisihan diatur pada Pasal 88 ayat(4) UU Jasa Konstruksi adalah sebagai berikut: (1) mediasi; (2) konsiliasi; dan (3) arbitrase. Selain itu Pasal 88 ayat(5) UU Jasa Konstruksi mengatur adanya keberadaan dewan sengketa yang dalam bagian Penjelasan UU Jasa Konstruksi diberikan pengertian sebagai tim yang dibentuk berdasarkan kesepakatan para pihak sejak pengikatan Jasa Konstruksi untuk mencegah dan menengahi sengketa yang terjadi di dalam pelaksanaan Kontrak Kerja Konstruksi.

Oleh karena itu, pada UU Jasa Konstruksi sengketa diajarkan untuk diselesaikan secara permusyawarahan serta pemufakatan yang diutamakan dilakukan di luar pengadilan. Tapi tetap harus memperhatikan Pasal 47 ayat(1) UU Jasa Konstruksi. Pada Pasal 47 ayat(1) UU Jasa Konstruksi, "salah satu klausula yang dipersyaratkan tercantum dalam Kontrak Kerja Konstruksi adalah ketentuan mengenai: (1) penyelesaian perselisihan, memuat ketentuan tentang tata cara penyelesaian perselisihan akibat ketidaksepakatan; dan (2) pilihan penyelesaian sengketa konstruksi". Pada penjelasan Pasal 47 ayat(1) UU Jasa Konstruksi terkait dengan penyelesaian sengketa diatur:

"Penyelesaian perselisihan memuat ketentuan tentang tatacara penyelesaian perselisihan yang diakibatkan antara lain oleh ketidaksepakatan dalam hal pengertian, penafsiran, atau pelaksanaan berbagai ketentuan dalam Kontrak Kerja Konstruksi serta ketentuan tentang tempat dan cara penyelesaian. Penyelesaian perselisihan ditempuh melalui antara lain musyawarah, mediasi, arbitrase, ataupun pengadilan".

Tidak terdapat penjelasan lebih lanjut terkait bedanya frase antara penyelesaian perselisihan dan penyelesaian sengketa. Jika berpedoman pada definisi "sengketa" pada KBBI, sengketa yang diartikan juga perselisihan. Prosedur penyelesaian perselisihan di luar pengadilan tepat untuk diimplementasikan terhadap perselisihan konstruksi yang alasannya berikut ini:

"Pertama, kerahasiaan mengenai sengketa. Kerahasiaan merupakan salah satu keunggulan dari mekanisme penyelesaian sengketa di luar jalur pengadilan, 
baik pada saat proses maupun terhadap putusan yang tidak dipublikasikan. Mengingat konstruksi terkait dengan banyak proses yang mana tidak seluruhnya dapat dibuka untuk umum, terutama apabila bangunan yang menjadi obyek sengketa termasuk dalam objek vital negara. Selain itu, diperlukan untuk menjaga hubungan baik di antara para pihak, mengingat pelaku usaha dalam bidang jasa konstruksi adalah terbatas. Kedua, para pihak dapat memilih pihak penengah (mediator/konsiliator/arbitrator) yang memiliki keahlian di bidang konstruksi."

Menurut Hellard, sengketa konstruksi dapat dibagi menjadi 4 (empat) kategori, yaitu: ${ }^{8}$

a. "Sengketa berkaitan dengan waktu (keterlambatan progress)";

b. "Sengketa berkaitan dengan finansial (klaim dan pembayaran)";

c. "Sengketa berkaitan dengan standar pekerjaan (desain dan hasil pekerjaan)";

d. "Konflik hubungan dengan orang-orang di dalam industri konstruksi".

Secara umum perselisihan-perselisihan di atas berhubungan dengan cara "langsung" ataupun "tidak langsung" dengan persoalan yang sifatnya teknik. Secara mendasar perjanjian jasa konstruksi adalah perjanjian yang sifatnya "khusus" yang mencantumkan berbagai hal teknik. Contohnya, perselisihan terkait dengan payment, melalui prosentage payment work progress yang diberlakukan sebagai persyaratan payment, yang membutuhkan hal-hal teknis yang berhubungan dengan penilaian work progress yang dapat ditagih. Oleh karena itu, untuk penyelesaian perselisihan konstruksi, tak hanya perlu ahli hukum, tapi butuh juga ahli ilmu lainnya, khususnya dalam aspek teknik untuk menyelami penyebab masalah.

Pada umumnya sengketa-sengketa tersebut atas akan berkaitan, baik secara langsung maupun tidak langsung dengan hal-hal bersifat teknis. Pada dasarnya Kontrak Kerja konstruksi merupakan kontrak yang bersifat khusus yang mana memuat banyak aspek teknis.Sebagai contoh, sengketa berkaitan dengan pembayaran dengan sistem prosentase progress pekerjaan sebagai syarat pembayaran, tentunya memerlukan aspek teknik terkait dengan penentuan progress pekerjaan yang dapat diklaim. Dengan demikian, dalam penyelesaian sengketa konstruksi, tidak saja dibutuhkan ahli hukum, namun diperlukan ahli pada disiplin ilmu lain, terutama aspek teknis, untuk memahami akar permasalahan.

Alasan selanjutnya mengenai prosedur penyelesaian perselisihan lewat usaha di luar pengadilan adalah:

"Ketiga, jangka waktu penyelesaian sengketa jelas dan relatif singkat. Walaupun perihal jangka waktu penyelesaian sengketa relatif singkat sebagai keunggulan dari mekanisme penyelesaian sengketa di luar pengadilan (arbitrase) menurut Undang-Undang Nomor 30 Tahun 1999 tentang Arbitrase dan Alternatif Penyelesaian Sengketa (selanjutnya disebut UU Arbitrase dan APS) tidak selalu terjadi karena di beberapa negara penyelesaian melalui jalur litigasi dapat ditempuh dengan waktu yang relatif singkat, namun saat ini harus diakui bahwa jalur litigasi memakan waktu yang lebih panjang dibandingkan dengan jalur di luar litigasi. Jangka waktu penyelesaian sengketa

8 R. Baden Hellard. (1988). Managing Construction Conflict. Longman Scientific \& Technical, hal. 89. 
yang singkat tentu lebih menguntungkan bagi para pihak yang bersengketa, karena dapat segera memperoleh kepastian mengenai penyelesaian atas sengketa yang sedang terjadi. Bagi pelaku usaha konstruksi, berlaku pula hal demikian karena sengketa konstruksi akan berkaitan dengan banyak hal seperti namun tidak terbatas pada kelangsungan pekerjaan, pengalihan bangunan, penggunaan bangunan oleh pengguna jasa, kepastian pembayaran. Khusus bagi penyedia jasa, sengketa yang berlarut-larut dapat menghambat keterlibatan penyedia jasa pada tender-tender proyek yang diselenggarakan oleh pengguna jasa yang sedang bersengketa".

\subsection{Perbandingan Penyelesaian Sengketa Kontrak Kerja Konstruksi Melalui Ajudikasi dan Arbitrase}

Penyelesaian sengketa melalui ajudikasi di Indonesia diadopsi oleh Otoritas Jasa Keuangan (OJK) untuk menyelesaikan sengketa pada sektor keuangan. Pada negara dengan "sistem hukum Common Law", ajudikasi sering digunakan untuk menyelesaikan sengketa kontrak konstruksi. Ajudikasi dalam Lembaga Alternatif Penyelesaian Sengketa Perbankan Indonesia (LAPSPI) diberikan pengertian sebagai berikut:

“Adjudikasi adalah cara penyelesaian sengketa di luar Arbitrase dan peradilan umum yang dilakukan oleh Adjudikator untuk menghasilkan suatu putusan yang dapat diterima oleh pemohon sehingga dengan penerimaan tersebut maka putusan dimaksud mengikat para pihak. Pada umumnya konflik yang terjadi antara dua belah pihak yang memiliki masalah diselesaikan di luar pengadilan, sedangkan cara penyelesaian lain di luar pengadilan biasa dikenal dengan Arbitrase."

Penyelesaian perselisihan dengan ajudikasi, dasarnya merupakan perselisihan yang kompleks dan khusus sekali (complicated). Tak semua orang bisa menyelesaikan, maka dibutuhkan ketrampilan yang spesial yang profesional. Contohnya saja pada perselisihan jasa konstruksi tak setiap orang bisa melakukan penyelesaian, dibutuhkan profesional ahli teknik.

Selama ini sering muncul sengketa konstruksi dan cenderung dalam penyelesaian sengketa yang ada tersebut masih belum dirasakan optimal hasilnya oleh para pihak yang bersengketa. Selama ini mereka memilih forum peradilan umum dan sebagian lagi melalui forum arbitrase. Persoalan biaya dan waktu serta penyelesaian sengketa yang lama masih menjadi kendala. Oleh sebab itu berkembanglah alternatif lain dalam penyelesaian sengketa yaitu ajudikasi. Praktek pada negara misalnya UK New Zealand, Australia, Singapura dan Malaysia telah memiliki aturan dan menjalani alternatif penyelesaian sengketa melalui jalur ajudikasi yang sangat berguna bagi pembangunan ekonomi nasional di negara masing-masing.

Ajudikasi (adjudication) dalam industri konstruksi adalah proses legal di mana seorang ajudikator ditunjuk dengan tujuan penyelesiaan perselisihan pihak-pihak yang bersengketa. Berbeda dengan negoisasi, konsiliasi, maupun mediasi yang mana keputusannya tidak mengikat secara hukum, hasil keputusan seoarang ajudikator mengikat. Tujuan utama dari dilakukannya ajudikasi adalah untuk menghemat waktu dan biaya dibandingkan dengan menyelesaikan sengketa melalui lembaga pengadilan. 
${ }^{9}$ Dalam FIDIC Red Book 1999, ajudikasi merupakan alternatif penyelesaian sengketa yang disarankan untuk dilakukan. Proses ajudikasi dilakukan dengan membentuk dewan ajudikasi sengketa (dispute adjudication board). Berbeda dengan arbitrase, dalam pelaksanaannya ajudikasi tidak memerlukan penghentian pelaksanaan pekerjaan. Dengan demikian proses ajudikasi ini dinilai lebih efektif karena tidak menghambat pelaksanaan pekerjaan di lapangan. ${ }^{10}$

Ajudikasi merupakan cara penyelesaian sengketa di luar arbitrase dan peradilan umum yang dilakukan oleh ajudikator untuk menghasilkan suatu putusan yang dapat diterima oleh Pemohon, sehingga dengan penerimaan tersebut maka putusan tersebut mengikat Termohon. Ajudikasi digunakan untuk mekanisme alternatif penyelesaian sengketa yang karateristiknya mirip dengan arbitrase. Oleh karena itu bisa dinyatakan bahwa ajudikasi adalah mekanisme arbitrase yang disederhanakan dan kemudian disesuaikan sedemikian rupa sehingga dapat memenuhi kebutuhan penyelesaian sengketa yang ritel dan kecil nilainya tersebut. Hal ini akan sangat tidak efisien, jika diselesaikan melalui arbitrase apalagi melalui peradilan umum.

Proses ajudikasi sesungguhnya simpel sekali. Jika muncul perselisihan, pihak-pihak yang bersangkutan membuat tahap-tahap sebagai berikut:

a. Para pihak membuat kesepakatan penyelesaian melalui ajudikasi,

b. Berdasar persetujuan ini, mereka menunjuk seorang ajudikator yang benarbenar profesional, (atau meminta lembaga penyelesaian sengketa menunjuk/mengangkat seorang ajudikator untuk menangani sengketa mereka),

c. Dalam kesepakatan itu, kedua belah pihak memberi kewenangan (authority) kepada ajudikator untuk mengabil keputusan (decision) yang mengikat kepada kedua belah pihak (binding to each party),

d. Sebelum mengambil keputusan, ajudikator dapat meminta informasi dari kedua belah pihak, baik secara terpisah maupun secara bersama-sama.

Mekanisme penyelesaian sengketa melalui ajudikasi perlu dipahami secara mendasar bagi Ajudikator Konstruksi, Penguna Jasa dan Penyedia Jasa. Pihak-pihak dalam melakukan pekerjaan pembangunan tidak lagi merasa takut dengan sengketa yang timbul, karena kedua belah pihak sudah mempercayai sistem ajudikasi dapat menyelesaikan persoalan tersebut.

Sebagai bahan perbandingan, perlu dikemukakan perkembangan terakhir di dunia internasional mengenai tumbuhnya secara signifikan ajudikasi sebagai prosedur yang cepat dalam penyelesaian sengketa untuk suatu sengketa konstruksi dan rekayasa (keteknikan). Seperti diketahui ajudikasi telah diperkenalkan di Inggris pada tahun 1998 berdasarkan UU di Inggris. Tujuan ajudikasi ini adalah untuk mempersiapkan bagi salah satu pihak yang membuat perjanjian jasa konstruksi untuk dapat memanggil (menunjuk) seorang ajudikator. Seorang ajudikator akan membuat sebuah keputusan yang mengikat tidak lebih dari 28 hari, dan Pengadilan harus siap untuk melaksanakan putusan itu (enforce).

\footnotetext{
9 Seng Hansen, S.T., M.Sc. (2015). Manajemen Kontrak Konstruksi, Jakarta: Gramedia, hal. 259.

10 Nazarkhan Yasin. (2004). Mengenal Klaim Konstruksi dan Penyelesaian Sengketa. Jakarta: Gramedia Pustaka Utama, hal.222.
} 
Selain di Inggris, Negara lain yang juga telah menetapkan prosedur ajudikasi serupa adalah Selandia Baru, Australia dan Singapura. Sementara Malaysia merupakan negara terakhir yang menetapkankan prosedur ajudikasi. Undang-Undang Pembayaran Industri Konstruksi dan Ajudikasi tahun 2012 telah mendapat persetujuan dari Kerajaan Malaysia pada tanggal 18 Juni 2012. Prosedur yang berlaku adalah untuk kontrak konstruksi, dan penunjukkan ajudikator oleh Kuala Lumpur Regional Centre for Arbitration (KLRCA). Ajudikator memiliki waktu 45 hari kerja setelah terbitnya jawaban (balasan) atas klaim, kemudian setelah itu ajudikator dapat mengeluarkan (membuat) sebuah putusan tertulis.

Undang-Undang Malaysia Tahun 2012 (CIPAA 2012) ini mensyaratkan para pihak awalnya untuk mengikuti mekanisme pembayaran yang telah diatur pada kontrak konstruksi mereka. Apabila satu pihak tetap belum dibayar, maka kemudian prosedur pra ajudikasi dapat dipergunakan. Ini mensyaratkan sebuah klaim pembayaran yang berdasarkan klaim belum dibayar pada kontrak konstruksi. Pihak termohon kemudian dapat mengakui klaim itu atau mempersengketakannya baik secara keseluruhan atau sebagiannya saja dalam jangka waktu 10 hari sejak klaim itu muncul. Sebuah sengketa yang telah secara jelas terjadi sejak adanya klaim dapat dirujuk ke ajudikasi.

Ajudikasi (adjudication) dalam industri konstruksi adalah proses legal di mana seorang ajudikator ditunjuk dalam rangka penyelesaian perselisihan pihak-pihak yang bersengketa. Berbeda dengan negoisasi, konsiliasi, maupun mediasi yang mana keputusannya tidak mengikat secara hukum, hasil keputusan seorang ajudikator mengikat. Tujuan utama dari dilakukannya ajudikasi adalah untuk menghemat waktu dan biaya dibandingkan dengan menyelesaikan sengketa melalui lembaga pengadilan. Proses ajudikasi dilakukan dengan membentuk dewan ajudikasi sengketa (dispute adjudication board) atau ajudikator tunggal (sole adjudicator). Berbeda dengan arbitrase, dalam pelaksanaannya ajudikasi tidak memerlukan penghentian pelaksanaan pekerjaan. Dengan demikian proses ajudikasi ini dinilai lebih efektif karena tidak menghambat pelaksanaan pekerjaan di lapangan. ${ }^{11}$

Mekanisme penyelesaian perselisihan lewat ajudikasi, sebenarnya sangat simpel. Bila ada perselisihan, maka para pihak akan melakukan langkah-langkah, yang diatur dalam Construction Industry Payment and Adjudication Act (CIPAA) 2012 yaitu: (a) para pihak membuat kesepakatan penyelesaian melalui ajudikasi Malaysia tidak perlu kesepakatan lagi karena sudah ada Undang-Undang Ajudikasi Konstruksi; (b) berdasar persetujuan ini, mereka menunjuk seorang ajudikator yang benar-benar profesional, (atau meminta lembaga penyelesaian sengketa menunjuk/mengangkat seorang ajudikator untuk menangani sengketa mereka); (c) dalam kesepakatan itu, kedua belah pihak memberi kewenangan (authority) kepada ajudikator untuk mengambil keputusan (decision) yang mengikat kepada kedua belah pihak (binding to each party); dan (d) sebelum mengambil keputusan, ajudikator dapat meminta informasi dari kedua belah pihak, baik secara terpisah maupun secara bersama-sama. Mekanisme penyelesaian sengketa melalui ajudikasi perlu dipahami secara mendasar oleh Ajudikator Konstruksi, Penguna Jasa dan Penyedia Jasa. Pihak-pihak dalam melakukan pekerjaan pembangunan tidak lagi merasa takut dengan sengketa yang timbul, karena kedua belah pihak sudah mempercayai sistem ajudikasi dapat menyelesaikan persoalan tersebut.

${ }^{11} \mathrm{Ibid}$, hal.222 
Dengan demikian, ajudikasi merupakan "cara penyelesaian sengketa di luar arbitrase dan peradilan umum yang dilakukan oleh ajudikator untuk menghasilkan suatu putusan yang dapat diterima oleh Pemohon, sehingga dengan penerimaan tersebut maka putusan tersebut mengikat Termohon". Ajudikasi digunakan "untuk mekanisme alternatif penyelesaian sengketa yang karakteristiknya mirip dengan arbitrase. Sehingga dapat dikatakan bahwa ajudikasi adalah mekanisme arbitrase yang disederhanakan dan kemudian disesuaikan sedemikian rupa sehingga dapat memenuhi kebutuhan penyelesaian sengketa yang ritel dan kecil nilainya tersebut". Hal ini akan sangat tidak efisien, jika diselesaikan melalui arbitrase apalagi melalui peradilan umum. Meskipun ajudikasi kelihatannya hampir sama dengan arbitrase, bahkan ada yang menyebutnya sebagai mini-arbitrase.

Persamaan antara arbitrase dan ajudikasi antara lain: proses hukumnya berdasarkan perundang-undangan dengan berdasarkan keadilan. Pemilihan pihak ketiga yaitu arbitrase atau ajudikasi dengan persetujuan para pihak. Jika persetujuan gagal dicapai selanjutnya ditunjuk lembaga lain untuk menyelesaikan. Resolusi atau penyelesaian diputus oleh pihak ketiga yang independen/bebas. Keputusan pihak ketiga ini dapat diajukan pembatalan kepada pengadilan yang lebih tinggi dan dapat dipaksakan eksekusinya oleh pengadilan. Persamaan selanjutnya baik arbitrase maupun ajudikasi boleh menggunakan lawyer atau tidak menggunakan lawyer.

Adapun perbedaan mendalam dari arbitrase dan ajudikasi dilihat dari tujuannya arbitrase untuk mengakhiri/mencari resolusi sengketa, sedangkan ajudikasi untuk mengelola sengketa dan mempertahankan cash flow. Sementara itu, prosesnya arbitrase mempunyai prosedur formal dan relatif lambat, sedangkan ajudikasi prosesnya informal dan ringkas serta relatif cepat. Bentuk proses arbitrase umumnya saling bermusuhan namun keadilannya dinilai baik, sedangkan ajudikasi bentuk prosesya inkusitorial dan/atau saling bermusuhan. Keadilan pada ajudikasi dinilai masih kasar. Mengenai biaya arbitrase pada umumnya lebih mahal dibandingkan dengan ajudikasi yang relatif tidak mahal.

Meskipun ajudikasi konstruksi disukai di negara-negara maju pada umumnya Singapura dan Malaysia serta NSW, Australia pada khususnya, namun ajudikasi sendiri bukannya tidak ada kelemahan/kekurangannya. Kelebihan dari ajudikasi meliputi: bukan sekedar proses resolusi tapi pengelolaan sengketa sebelum menjadi serius; dapat menyelesaikan secara cepat ketika sengketa timbul, tidak harus pekerjaan selesai dahulu, menjaga cash flow; relatif cepat, mudah dan efektif; dan melibatkan pendapat ahli yang bebas dari kepentingan, kecuali dalam hal maintaining cash flow. Sementara itu kekurangan dari ajudikasi diantaranya bagi perusahaan besar harus memaintain organisasi ajudikasi yang besar; dan para profesional akan lebih sering menghadapi klaim untuk kelalaian atau wanprestasi tugas.

Terkait dengan kewenangan ajudikator, maka ajudikator dapat membuat prosedur untuk ajudikasi serta perintah untuk mengungkap dan penyiapan dokumen serta menetapkan batas akhir prosesnya. Jelasnya ajudikator dapat menggunakan segenap pengetahuan dan keahliannya dalam memeriksa dan memutus sengketa itu serta dapat pula menunjuk ahli independen untuk dimintakan pendapatnya (tetapi hanya dengan persetujuan para pihak). Ajudikator juga dapat menghadirkan saksi yang tersumpah. Kewenangan untuk memeriksa dan merevisi sertifikat (akta) dan dokumen lain yang secara tegas telah ditetapkan. Sebagai tambahan seorang ajudikator dapat juga membebankan biaya dan bunga. Para pihak dapat menyetujui mengenai hal 
ajudikator dan besaran uang bayarannya. Akan tetapi bila mereka gagal untuk bersepakat maka kemudian standar persyaratan cara penunjukan dan besaran uang bayarannya menggunakan standar yang akan diterapkan nantinya. Hal ini ada dalam Peraturan Lembaga Alternatif Penyelesaian Sengketa Perbankan Indonesia Nomor: 02/LAPSPI-PER/2017 tentang Peraturan dan Prosedur Adjudikasi.

Para pihak secara bersama sama dan secara tanggung renteng menanggung hal ini. Banyak kesamaan dan cara dengan undang undang lain di seluruh dunia. Namun demikian, untuk perlindungan akan bayaran-bayaran kewajiban para pihak kepada ajudikator dapat dimintakan dalam bentuk deposit yang ditempatkan terlebih dahulu. Seorang ajudikator memiliki hak tertentu dalam undang undang dan menjadikannya tidak mungkin untuk mengeluarkan keputusan sampai hak pembayaran telah terpenuhi. Konsepsi harus mengatur bahwa sebuah keputusan ajudikator bersifat rahasia. Hal ini menjadi kebaharuan yang memasukkan kekhususan mengenai ketentuan kerahasian yang dimaksudkan untuk mengantisipasi persoalan mendasar yang sering diabaikan; yaitu soal imunitas seorang ajudikator. Oleh karena itu, tidak ada upaya atau gugatan yang dapat diajukan terhadap ajudikator untuk setiap tindakan dan kelalaian yang dilakukan dengan itikad baik.

Putusan ajudikasi mengikat kecuali ditolak ketika diajukan banding ke Pengadilan Tinggi dan untuk akhirnya harus diputuskan atau tunduk pada penyelesaian yang disetujui kedua pihak. Konsepsi yang diusulkan juga secara khusus memuat cara pelaksanaan atas sebuah putusan ajudikasi. Salah satu pihak dapat memintakan pelaksanaan atas sebuah putusan ajudikasi dengan cara memohonkannya kepada pengadilan tinggi. Selanjutnya ketentuan atas pembayaran terbatas mewajibkan pembayaran sementara (sela) dibuat sehubungan dengan kontrak konstruksi. Apabila cara pembayaran tidak ditentukan secara khusus, maka kemudian pembayaran dibuat secara bulanan.

\section{Kesimpulan}

Penyelesaian sengketa konstruksi di Indonesia diatur dalam Pasal88 Undang-Undang Nomor 2 Tahun 2017 tentang Jasa Konstruksi yaitu dalam hal upaya penyelesaian sengketa tidak tercantum dalam kontrak kerja konstruksi para pihak yang bersengketa membuat suatu persetujuan tertulis mengenai tata cara penyelesaian sengketa yang akan dipilih. Tahapan upaya penyelesaian sengketa meliputi: Mediasi, Konsiliasi, dan Arbitrase. Dalam pelaksanaan Mediasi, Konsiliasi, dan Arbitrase tersebut dapat mengacu pada Undang-Undang Nomor 30 Tahun 1999 tentang Arbitrase dan Alternatif Penyelesaian Sengketa. Ajudikasi dipergunakan untuk mekanisme alternatif penyelesaian sengketa yang karakteristiknya mirip dengan arbitrase. Sehingga dapat dikatakan bahwa ajudikasi adalah mekanisme arbitrase yang disederhanakan dan kemudian disesuaikan sedemikian rupa sehingga dapat memenuhi kebutuhan penyelesaian sengketa yang adil. Ajudikasi keuntungannya ialah bukan hanya prosedur penyelesaian perselisihan, tetapi juga sebagai sarana mengelola sengketa sebelum menjadi serius. Hal tersebut memungkinkan sebuah penyelesaian yang cepat ketika suatu sengketa muncul, bukan ketika pekerjaan sudah terhenti/selesai. Karenanya, hal itu memungkinkan pekerjaan berjalan tanpa hambatan dan cash flow tetap terjaga. 


\section{Daftar Pustaka / Daftar Referensi}

\section{Buku :}

Adams, Tony Mc. (2002). Law Bussiness Society. Boston: Irwin.

Badan Pusat Statistik. (2018). Survey Perubahan Konstruksi Tahun 2018. Jakarta.

Diantha, I Made Pasek. (2017). Metodologi Penelitian Hukum Normatif dalam Justifikasi Teori Hukum. Jakarta: Prenada Media Group.

Hellard, R. Baden. (1988). Managing Construction Conflict. Longman Scientific \& Technical.

Hansen, Seng. (2015). Manajemen Kontrak Konstruksi. Jakarta: Gramedia Pustaka Utama.

Rajagukguk, Eman. (2001). Arbitrase dalam Putusan Pengadilan. Jakarta: Chandra Pratama.

Soekanto, Soerjono dan Mahmudji, Sri. (2013). Penelitian Hukum Normatif, Suatu Tinjauan Singkat. Jakarta: Raja Grafindo Persada.

Usman, Rachmadi. (2013). Pilihan Penyelesaian Sengketa di Luar Pengadilan. Bandung: PT Citra Aditya Bakti.

Yasin, Nazarkhan. (2004). Mengenal Klaim Konstruksi dan Penyelesaian Sengketa. Jakarta: Gramedia Pustaka Utama.

Sugiyono, 2009, Metode Penelitian Kuantitatif Kualitatif dan RED; Alfabeta, Bandung. Sugiyono, 2013, Cara mudah menyusun Skripsi, Tesis, dan Disertasi; Alfabeta, Bandung. Sugiyono, 2014, Statistika untuk Penelitian; Alfabeta, Bandung.

Sugiyono, 2015, Metode Penelitian Manajemen. Alfabeta, Bandung.

Tanielian, Adam, 2012, Risk Management in Construction Projects.

Thomas Haugen,Amarjit Singh, F.ASCE, 2014, Dispute Resolution Strategy Selection.

William R. Wildman, Laura J. Stipanowich, 2013, Class Arbitration and the Construction Dispute: Analysis of Current Jurisprudence and Practical Tips for the Construction Practitioner.

\section{Jurnal Ilmiah :}

Djatnika, Suntana S.. (2017). "Persengketaan Dalam Perjanjian Konstruksi". Jurnal Indonesia Arbitration Quarterly Newsletter, Vol.9, No.2.

\section{Peraturan Perundang-Undangan :}

Kitab Undang-Undang Hukum Perdata.

Undang-Undang Nomor 30 Tahun 1999 tentang Arbitrase dan Alternatif Penyelesaian Sengketa dan Tambahan Lembaran Negara Republik Indonesia Nomor 3872.

Undang-Undang Nomor 2 Tahun 2017 tentang Jasa Konstruksi dan Lembaran Negara Republik Indonesia Tahun 2017 Nomor 11.

Undang-Undang Malaysia Tahun 2012:The Construction Industry Payment and Adjudication Act 2012 (CIPAA 2012). 